\title{
PERSEPSI GURU PAMONG TENTANG PELAKSANAAN PENGALAMAN LAPANGAN KEPENDIDIKAN MAHASISWA GEOGRAFI DI SMA NEGERI KOTA PADANG SEMESTER JULI-DESEMBER TAHUN 2018
}

\author{
Warda $^{1}$, Rahmanelli ${ }^{2}$ \\ Program Studi Pendidikan Geografi \\ Fakultas Ilmu Sosial, Universitas Negeri Padang \\ Email: Wardahhh271097@gmail.com
}

\begin{abstract}
ABSTRAK
Penelitian ini bertujuan untuk menganalisis persepsi pamong tentang pelaksanaan PLK mahasiswa geografi dalam kegiatan teaching dan non-teaching di SMA negeri Kota Padang semester JuliDesember tahun 2018. Jenis penelitian ini adalah penelitian gabungan (mixed method). Lokasi penelitian dilakukan di seluruh SMA Negeri Kota Padang yang menerima mahasiswa Praktek Lapangan Kependidikan (PLK) dengan subjek penelitian yaitu 18 guru pamong yang membimbing mahasiswa program studi pendidikan Geografi. Teknik pemilihan subjek penelitian yaitu dengan teknik purposive. Teknik pengumpulan data dengan observasi, wawancara dan dokumentasi. Penelitian ini menemukan bahwa: (1) Persepsi guru pamong tentang kegiatan teaching telah baik tetapi masih ada beberapa kelemahan dan adanya ketidaksesuaian hasil wawancara dengan nilai tertulis yang ada di buku penilaian yang diberikan oleh UPPL. (2) Persepsi guru pamong tentang kegiatan non-teaching sudah dinilai aktif oleh guru pamong. Mahasiswa PLK telah melaksanakan kegiatan non-teaching yang telah diatur oleh masing-masing sekolah baik kegiatan piket, upacara, ekstrakurikuler dan kegiatan lainnya.
\end{abstract}

Kata kunci: persepsi, guru pamong, pelaksanaan PLK

\section{ABSTRACT}

This research aims to analyse the perception of the tutor about the implementation of students in the geography of teaching and non-teaching activities in the Padang City High School semester from July to December year 2018. This type of research is mixed method. The research location is conducted in all of the Padang City High School which receives Student education field practice (PLK) with the research subject of 18 tutor teachers guiding students of Geography education course. The technique of research subject selection is with purposive technique. Data collection techniques with observation, interviews and documentation. The study found that: (1) perceptual perception of teaching activities has been good but there are still some weaknesses and mismatches of interviews with written values in the assessment book given by UPPL. (2) The perception of teacher tutor about non-teaching activities has been assessed actively by tutor. PLK students have carried out non-teaching activities that have been governed by each of the schools of both picket activities, ceremonies, extracurricular and other activities.

Keywords: perception, tutor teacher, implementation of the PLK

\footnotetext{
1. Mahasiswa Program Studi Pendidikan Geografi Fakultas Ilmu Sosial

2. Dosen Jurusan Geografi Fakultas Ilmu Sosial, Universitas Negeri Padang
} 


\section{Pendahuluan}

Undang-Undang Nomor 20 Tahun 2003 Bab II Pasal 3 tentang Sistem Pendidikan Nasional mengatakan bahwa fungsi pendidikan di Negara Indonesia yaitu berfungsi untuk mengembangkan kemampuan dan membentuk watak serta peradaban bangsa yang bermartabat dalam rangka mencerdaskan kehidupan bangsa, bertujuan untuk berkembangnya potensi peserta didik agar menjadi manusia yang beriman dan bertaqwa kepada Tuhan Yang Maha Esa, berakhlak mulia, berilmu, sehat, kreatif, cakap, mandiri, dan menjadi warga negara yang demokratis serta bertanggung jawab.

Pendidikan memiliki kaitan yang kuat terhadap kegiatan pembelajaran. Kegiatan pembelajaran merupakan satu sistem yang berisi sejumlah aktivitas guru dan peserta didik akan landasan interaksi berbalasan yang berjalan pada keadaan edukatif demi menggapai maksud dan tujuan tertentu (Usman 2001).

Guru memegang peran utama dalam pembangunan dan pengembangan pendidikan, khususnya yang diselenggarakan secara formal di sekolah. Guru sangat memegang pengaruh terhadap kegiatan proses dan hasil pendidikan yang bermutu. Maka dari itu usaha dan upaya penyempurnaan pun dilakukan guna meningkatkan mutu pendidikan tidak akan terlaksana secara relevan tanpa didukung oleh guru profesional dan bermutu. Guru yang profesional akan makin bisa mewujudkan tempat yang efesien dan sanggup mengolah kegiatan pembelajaran. Jadi kesuksesan proses pembelajaran benar-benar ditentukan oleh keterampilan guru dalam kegiatan pembelajaran.

Universitas Negeri Padang adalah suatu lembaga pendidikan yang memiliki jalur kependidikan yang amat berfungsi dalam melahirkan guru yang profesional. Dapat dilihat dari motonya alam takambang jadi guru yang berarti alam terkembang jadi guru, yaitu agar kita belajar dari alam yang menyajikan berbagai fenomena dan sesunggungnya alam merupakan sumber belajar dan sumber ilmu bagi setiap manusia. Salah satu usaha yang dilakukan Universitas Negeri Padang untuk melahirkan seorang pendidik yang berkompeten yaitu dengan menyediakan satu mata kuliah yang merupakan kegiatan praktik yang disebut dengan Pengamalan Lapangan Kependidikan (PLK).

Kegiatan Pengalaman Lapangan Kependidikan mencakup dua kegiatan yaitu kegiatan Teaching dan kegiatan Non-teaching. Kegiatan Teaching merupakan kegiatan yang berkaitan dengan seluruh kegiatan pembelajaran, seperti praktik mengajar, praktik bimbingan dan konseling, praktik administrasi serta kegiatan yang bersifat kokurikuler. Sedangkan kegiatan Non-teaching merupakan kegiatan yang dilakukan diluar proses mengajar, kegiatan Non-teaching meliputi: upacara bendera, piket 
pustaka, tugas administrasi sekolah dan ekstra kurikuler yang berlangsung disekolah mitra.

Pengalaman menjadi guru menghadapi peserta didik di dalam kelas dan situasi persekolahan yang nyata sangat diperlukan bagi mahasiswa calon guru atau pendidik, agar memiliki kompetensi pendidik dan siap menjadi guru setelah menyelesaikan studinya di Universitas Negeri Padang.

Menurut Undang-Undang Nomor 14 Tahun 2005 tentang Guru dan Dosen, seorang guru dikatakan berkompeten apabila menguasai empat kompetensi dasar yaitu kompetensi pedagogik, kompetensi kepribadian, kompetensi sosial dan kompetensi profesional. Seorang mahasiswa yang melaksanakan PLK di sekolah pun diharuskan untuk menguasai empat kompetensi tersebut, karena seorang mahasiswa praktikan di sekolah sudah dianggap sebagai seorang guru yang turut serta dalam pelaksanaan pembelajaran di sekolah.

Mulyasa dalam Musfah (2011), "Kompetensi guru adalah gabungan antara kemampuan personal, perilaku, teknologi, sosial dan spiritual yang secara utuh membrntuk kompetensi standar profesi guru yang mencakup penguasaan materi, pemahaman terhadap peserta didik, pembelajaran yang mendidik, pengembangan pribadi dan personalitas".

Mahasiswa Jurusan Geografi khusus program studi pendidikan geografi umumnya melaksanakan
Pengalaman Lapangan Kependidikan di Kota Padang dan ada juga diluar Kota Padang. Namun hal ini tidak mengubah dan tidak ada perbedaan kegiatan PLK yang dilakukan. Selama kegiatan Pengalaman Lapangan Kependidikan ini dilaksanakan mahasiswa praktik akan dibimbing oleh guru mata pelajaran geografi yang mengajar disekolah tersebut.

Mahasiswa yang melakukan Pengelaman Lapangan Kependidikan ada beberapa kesulitan yang berbeda dialami saat kegiatan PLK dilaksanakan. Walaupun mahasiswa sudah mengambil matakuliah micro teaching dan sudah melakukan praktek mengajar selama satu semester, yang mana teman sekelas menjadi muridnya tetapi tetap saja keadaan setelah terjun langsung kelapangan sangat berbeda dengan saat praktek dikelas. Keterampilan mahasiswa PLK geografi pada perihal perencanaan pembelajaran pun masih kurang baik. Mulai dari pembuatan silabus, RPP, bahan ajar, LKPD dan perangkat mengajar lainnya. Selain masih kurang dalam hal perangkat pembelajaran, kemampuan mahasiswa PLK selama proses belajar mengajar juga masih terdapat banyak kekurangan sehingga selama proses belajar mengajar situasinya tidak kondusif.

Selain itu, mahasiswa PLK geografi wajib terlibat didalam kegiatan sekolah seperti upacara bendera, piket dan ekstarkurikuler. Masing-masing sekolah sudah menetapkan jadwal untuk kegiatan 
tersebut, tetapi ada beberapa mahasiswa yang lari dari tanggungjawabnya atau tidak mengerjakan tugas sesuai dengan jadwal yang tertera.

\section{Metode Penelitian}

Jenis penelitian yang digunakan adalah penelitian yang menggunakan metode penelitian gabungan (Mixed Method) dengan pendekatan kuantitatif dan kualitatif (Abbas, 2010). Penelitian ini dilakukan di seluruh SMA Negeri di Kota Padang yang menerima mahasiswa praktek lapangan kependidikan (PLK). Subjek penelitian ini adalah seluruh guru pamong yang membimbing mahasiswa program studi pendidikan Geografi yang berjumlah 18 orang. Teknik pemilihan subjek penelitian dilakukan dengan teknik purposive. Teknik pengumpulan data yang digunakan adalah obsevasi, wawancara dan dokumentasi. Teknik analisis yang dipakai adalah catatan lapangan, reduksi data, penyajian data, verifikasi data, penarikan kesimpulan, dan persentase. Teknik keabsahan data yang digunakan adalah perpanjangan pengamatan, meningkatkan ketekunan, triangulasi, dan diskusi dengan teman sejawat.

\section{Hasil dan Pembahasan}

Persepsi pamong tentang pelaksanaan PLK Mahasiswa Geografi dalam kegiatan teaching dari hasil wawancara terkait persiapan hingga pelaksanaannya masih banyak ditemukan kekurangan. Pada umumnya guru pamong menilai mahasiswa PLK masih banyak kekurangan dari persiapan perangkat, pengelolaan kelas, dan penguasaan materi. Sedangkan guru pamong memberi penilaian positif pada penggunaan media dan metode pembelajaran yang digunakan.

\section{Pelaksanaan}

program

Pengalaman Lapangan Kependidikan (PLK) yang dilaksanakan bukan hanya melatih mahasiswa untuk tahu dan merasakan menjadi seorang guru di dalam kelas saja tetapi mahasiswa dituntut untuk bisa membuat persiapan sebelum masuk ke kelas. Kelengkapan Mahasiswa PLK Geografi dalam menyiapkan perangkat dan proses mengajar di dalam kelas disajikan pada tabel 1 dan 2 sebagai berikut.

Tabel 1. Kelengkapan Perangkat Mahasiswa PLK Geografi

\begin{tabular}{llccccccc}
\hline No & Aspek & Lengkap & $\%$ & $\begin{array}{c}\text { Kurang } \\
\text { Lengkap }\end{array}$ & $\%$ & $\begin{array}{c}\text { Tidak } \\
\text { Lengkap }\end{array}$ & $\%$ & Frekuensi \\
\hline 1 & Silabus & 12 & 67 & 6 & 33 & 0 & 0 & 18 \\
2 & RPP & 15 & 83 & 3 & 17 & 0 & 0 & 18 \\
3 & Bahan Ajar & 17 & 94 & 1 & 6 & 0 & 0 & 18 \\
4 & LKPD & 17 & 94 & 1 & 6 & 0 & 0 & 18 \\
5 & Media & 18 & 100 & 0 & 0 & 0 & 0 & 18 \\
\hline
\end{tabular}

Sumber : Hasil olahan data primer 2019 
Tabel 2. Penilaian Proses Mahasiswa PLK Geografi saat mengajar di kelas

\begin{tabular}{|c|c|c|c|c|c|c|c|c|}
\hline No & Aspek & Baik & $\%$ & $\begin{array}{c}\text { Cukup } \\
\text { Baik }\end{array}$ & $\%$ & $\begin{array}{c}\text { Kurang } \\
\text { Baik }\end{array}$ & $\%$ & Frekuensi \\
\hline 1 & Pengeloaan Kelas & 5 & 28 & 3 & 17 & 10 & 55 & 18 \\
\hline 2 & $\begin{array}{l}\text { Mengaitkan Materi dan } \\
\text { Meninjau Kembali Inti } \\
\text { Pembelajaran }\end{array}$ & 1 & 5 & 12 & 67 & 5 & 28 & 18 \\
\hline 3 & Penguasaan Materi & 6 & 33 & 9 & 50 & 3 & 17 & 18 \\
\hline 4 & $\begin{array}{l}\text { Penguasaan dan } \\
\text { Pemanfaatan IT }\end{array}$ & 12 & 67 & 5 & 28 & 1 & 5 & 18 \\
\hline 5 & Evaluasi Pembelajaran & 7 & 39 & 9 & 50 & 2 & 11 & 18 \\
\hline
\end{tabular}

Sumber : Hasil olahan data primer 2019

Berdasarkan tabel 1 dan tabel 2, mahasiswa PLK geografi masih rendah dalam mempersiapkan perangkat mengajar dan masih lemah selama didalam proses pembelajaran dikelas. Namun, hasil berbeda didapatkan pada saat penilaian di buku nilai PLK yang diberikan oleh UPPL UNP. Buku nilai tersebut diisi oleh guru pamong dan dosen pembimbing yang berisikan nilai mahasiswa geografi yang melaksanakan PLK. Nilai yang diberikan oleh guru pamong terhadap mahasiswa pada tiga aspek yaitu Latihan Mengajar Terbimbing (LMT), Latihan Mengajar Mandiri (LMM) dan non-teaching. Nilai rata-rata mahasiswa geografi yang melaksanakan PLK semester ganjil tahun pelajaran 2018/2019 sudah menunjukkan rata-rata nilai yang sangat memuaskan yaitu nilai A. Maka terjadinya ketidaksesuaian hasil wawancara yang berisikan persepsi guru pamong terhadap pelaksanaan PLK dengan nilai tertulis yang ada di buku penilaian yang diberikan oleh UPPL.
Ketidaksesuaian yang terjadi dari hasil wawancara dan nilai tertulis pada buku penilaian seharusnya tidak terjadi. Hal-hal seperti ini apabila tidak dirubah maka akan terus terjadi dari masa ke masa, yang menyebabkan mahasiswa menganggap PLK ini walaupun tidak dilaksanakan dengan serius tetap akan mendapatkan nilai yang tinggi. Padahal pelaksanaan PLK memiliki tujuan salah satunya memberi pengalaman nyata kepada mahasiswa agar dapat merasakan dan menjiwai tugas-tugas sebagai seorang pendidik. Setelah menyelesaikan PLK mahasiswa diharapkan dapat memiliki kompetensi pendidik, yaitu kompetensi pedagogik, kompetensi kepribadian, kompetensi sosial dan kompetensi profesional.

Pelaksanaan kegiatan nonteaching ini berkaitan dengan kompetensi sosial yang dimana merupakan kemampuan pendidik sebagai bagian dari masyarakat untuk berkomunikasi dan bergaul secara efektif dengan peserta didik, sesama pendidik, tenaga kependidikan, orang 
tua/wali peserta didik, dan masyarakat sekitar.

Persepsi pamong tentang pelaksanaan PLK Mahasiswa Geografi dalam kegiatan non-teaching sudah dinilai baik. Mayoritas Mahasiswa PLK geografi semester ganjil tahun pelajaran 2018/2019 melaksanakan kegiatan seperti piket, upacara, ekstrakurikuler dan kegiatan lainnya sudah aktif, tidak ada yang bermasalah, dan membuat guru pamong terkesan dengan adabtasi mahasiswa PLK. Hasil wawancara dan nilai yang tertera pada buku nilai sudah sesuai, rata-rata mahasiswa sudah mendapatkan nilai $>80$ yang menandakan mahasiswa geografi yang melaksanakan PLK sudah baik dalam kegiatan non-teaching.

Tabel 3. Nilai Non-teaching Mahasiswa PLK Geografi Semester Ganjil T.P 2018/2019

\begin{tabular}{ccc}
\hline No & Nilai & Jumlah Mahasiswa \\
\hline 1. & $80-83$ & 2 Orang \\
2. & $84-87$ & 6 Orang \\
3. & $88-91$ & 5 Orang \\
4. & $92-96$ & 19 Orang \\
\hline & Jumlah & 32 Orang
\end{tabular}

Sumber: Olahan data primer dari UPPL UNP 2019

Susanto (2013), mengatakan bahwa kemampuan berbahasa lisan meliputi kemampuan berbicara dan menyimak. Ini menandakan bahwa kemampuan lisan para mahaiswa PLK semester ganjil tahun pelajaran 2018/2019 sudah dapat dikatan baik. Guru bukan hanya sebagai sebagai orang yang mengajar didepan kelas tetapi guru juga menjadi contoh di lingkungan sekolah atau tempat tinggalnya.

\section{Kesimpulan}

Berdasarkan penelitian yang telah dilakukan maka dapat ditarik kesimpulan yaitu sebagai berikut :

1. Persepsi guru pamong terhadap kegiatan teaching pelaksanaan
PLK mahasiswa geografi tahun pelajaran 2018/2019 semester ganjil telah baik tetapi masih ada beberapa kelemahan. Guru pamong menilai mahasiswa PLK masih lemah dalam persiapan perangkat pembelajaran, pengelolaan kelas, dan penguasaan materi. Penilaian guru pamong memberi penilaian positif pada mahasiswa PLK dalam penggunaan media dan metode pembelajaran. Tetapi adanya ketidaksesuaian hasil wawancara dengan nilai tertulis yang ada di buku penilaian yang diberikan oleh UPPL. Pada buku nilai, mahasiswa 
mendapatkan rata-rata nilai yang tinggi sedangkan hasil wawancara guru pamong masih ada mahasiswa PLK kekurangannya.

2. Persepsi guru pamong terhadap kegiatan non-teaching pelaksanaan PLK mahasiswa geografi tahun pelajaran 2018/2019 semester ganjil sudah dinilai aktif oleh guru pamong. Mahasiswa PLK sudah melaksanakan kegiatan nonteaching yang telah diatur oleh masing-masing sekolah baik kegiatan piket, upacara, ekstrakurikuler dan kegiatan lainnya. Begitupun adaptasi mahasiswa PLK yang telah baik, bisa berbaur dan bergaul dengan masyarakat sekolah. Hasil wawancara sudah sesuai dengan nilai yang ada di buku penilaian.

\section{Daftar Pustaka}

Abbas, Tashakkori. 2010. Hanbook of Mixed Method I Social \& Behavioral Reserch. Jakarta: Pustaka Belajar.

Musfah, Jejen. 2011. Peningkatan Kompetensi Guru Melalui Pelatihan dan Sumber Belajar Teori dan Praktik. Jakarta: Kencana.

Susanto, Ahmad. 2013. Teori Belajar dan Pembelajaran di Sekolah Dasar. Jakarta: Kencana Prenadamedia Group.
Usman dan Setiawati. 2001. Upaya Optimalisasi Kegiatan Belajar Mengajar. Bandung: Remaja Rosdakarya.

Undang-Undang Republik Indonesia No 20 Tahun 2003 Tentang Sistem Pendidikan Nasional.

Undang-Undang Republik Indonesia No 14 Tahun 2005 Tentang Guru dan Dosen. 